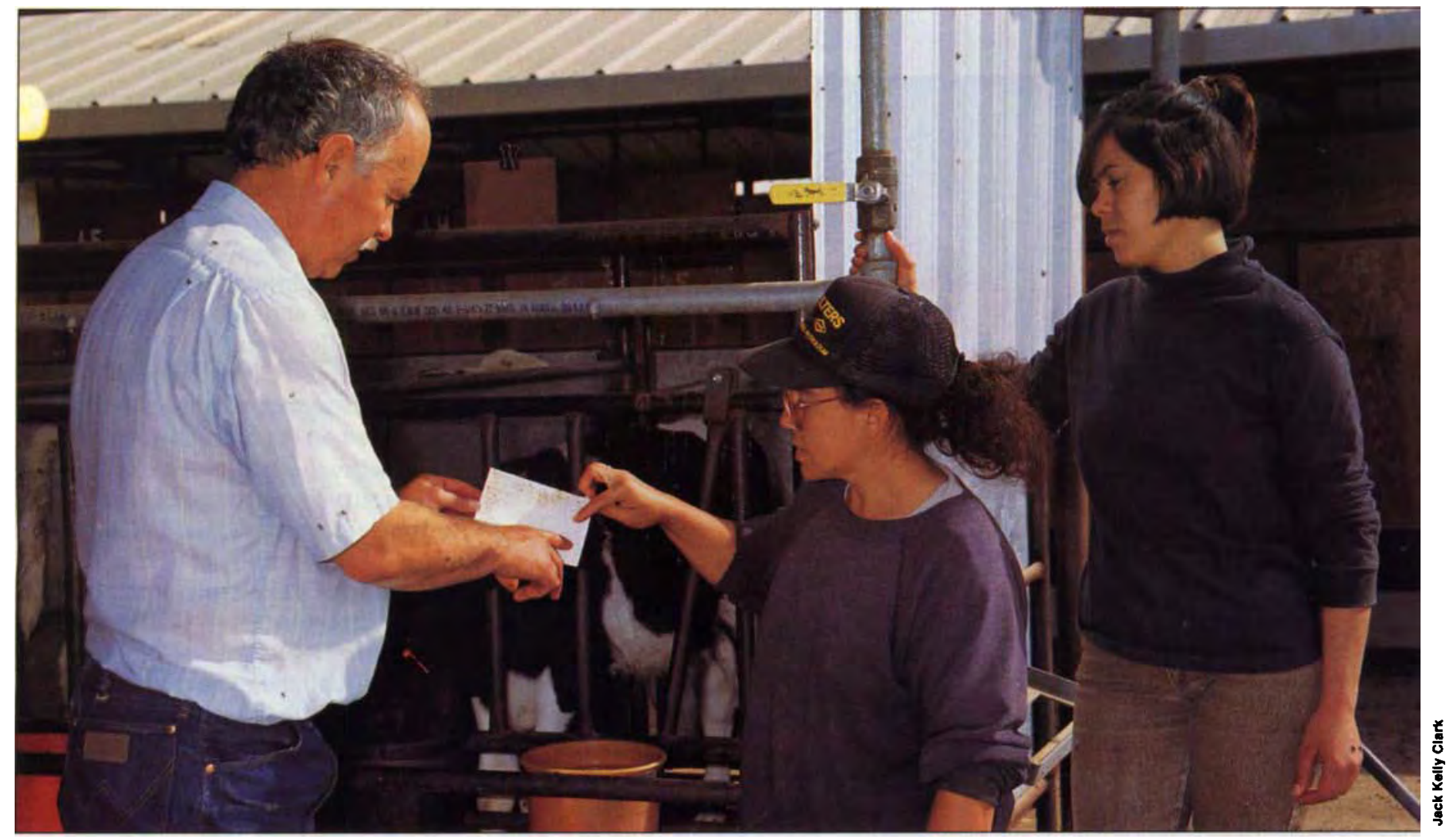

\title{
For wages and benefits, bigger dairies may be better
}

Above, production was slightly higher for dairies that regularly offer employees additional training after hiring.

\section{Barbara Reed}

California recently surpassed Wisconsin as the nation's numberone dairy state. To be productive, California's dairies rely heavily on hired labor. However, wages and benefits offered to dairy employees are highly variable. Herd managers and milkers earn more on larger dairies. Union employees out-earn their non-union counterparts in wages and benefits. Although managerial treatment of employees is not highly variable, some practices such as team training or providing continuing education may influence herd productivity. Well-trained employees may increase herd productivity through improving disease detection and prevention, and increasing the effectiveness of breeding and nutrition programs.
With few exceptions, hired labor is essential for the operation of California dairies. The state's 1 million dairy cattle are some of the most productive in the nation, averaging more than $19,000 \mathrm{lb}$ of milk per cow per year. California's dairies are also among the largest. Herds of a thousand cows or more are common in parts of the San Joaquin Valley and Southern California. Statewide, the average herd size is already more than 500 cows and rising annually.

Demands on dairy labor are changing as the industry grows. Labor is becoming more specialized, employees are expected to be more productive and competition for skilled labor is increasing.

In contrast to migrant or seasonal agricultural jobs, most dairy employment is permanent and year-round. The opportunity for a regular pay-

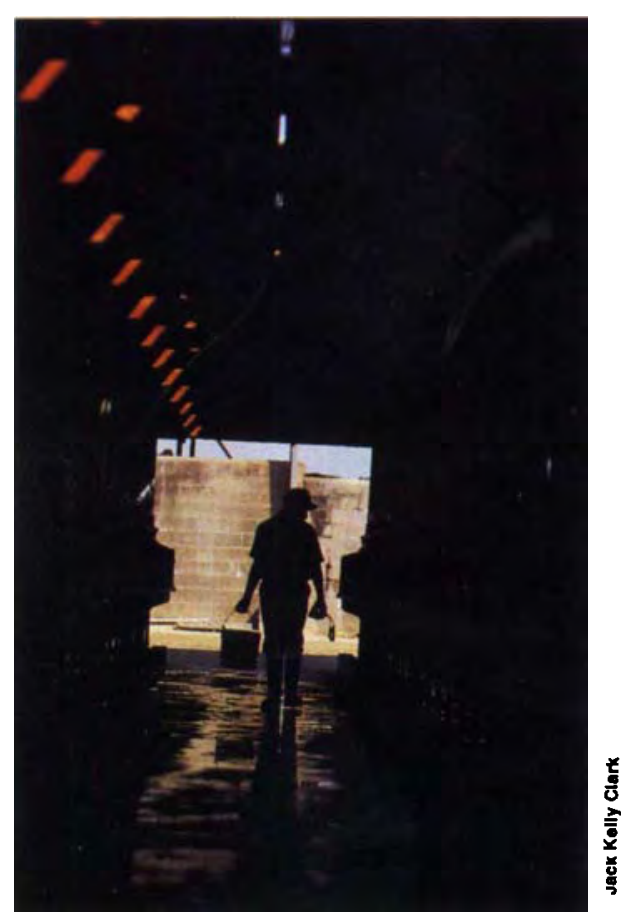




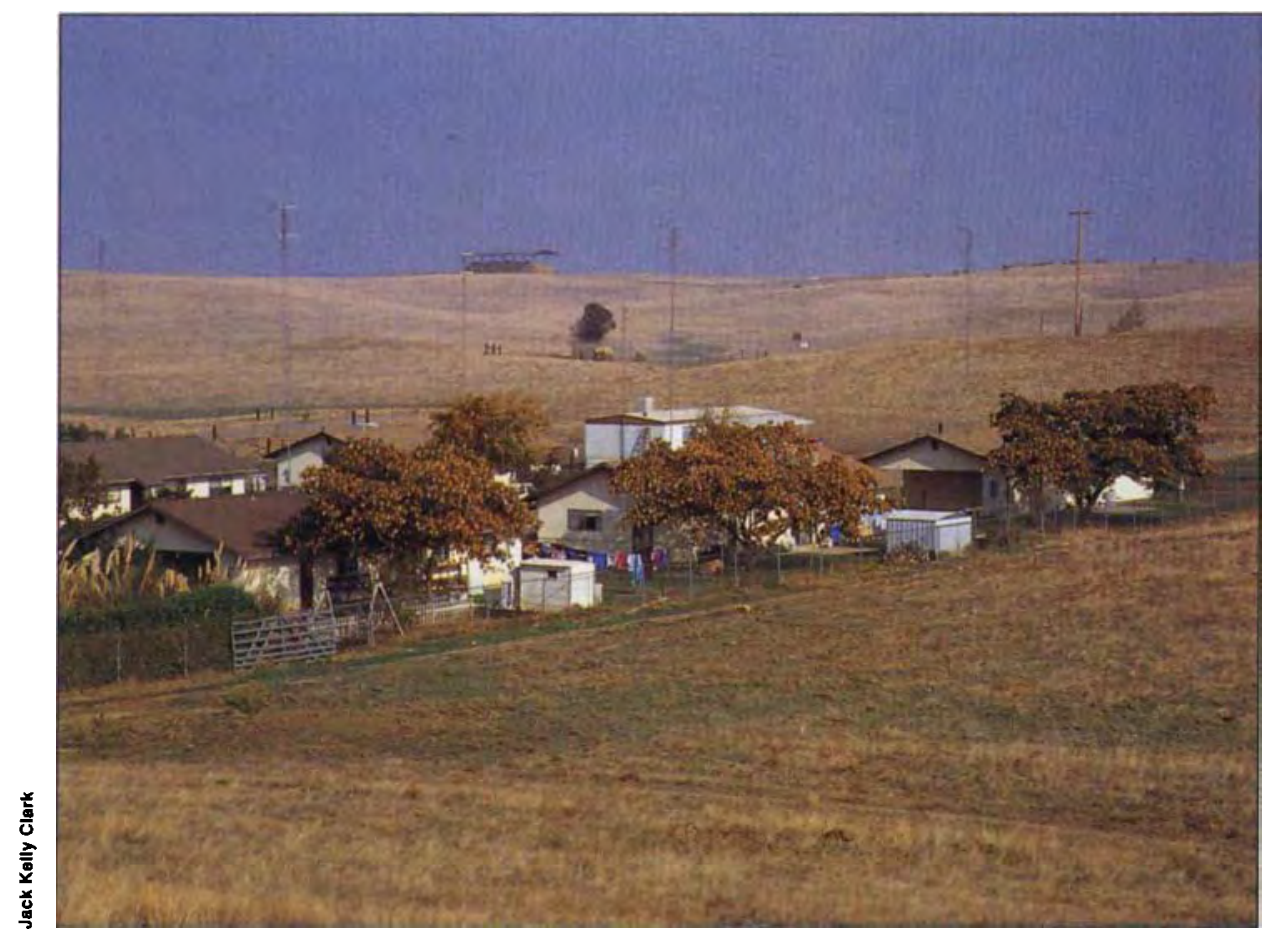

Wages and benefits were significantly better for dairy employees who belonged to unions and who worked at larger dairies. Free housing, like that shown above, and utilities are provided to many dairy employees and their families.

check comes with a price, however. Whether a worker is assisting with a difficult calving, milking at 3 a.m. or feeding cows, the work goes on every day of the year around the clock.

Dairy work is extremely demanding. At the very least, it can be monotonous (milking for 8 hours) and at its worst, dangerous (handling bulls).

A dairy owner's decisions regarding scheduling, training and pay for the work force are determined by: (1) herd size and how it is managed (feeding, number of milkings, level of production); (2) owners' attitudes and beliefs about labor management and their personal ability as labor managers; and (3) financial status of the farm (cash flow, debt service).

Dairy owners face many challenges in attracting and keeping employees. They must not only compensate employees adequately for the work performed, but they must also offer competitive schedules, benefits and training. If they do not succeed in attracting and keeping a skilled work force, they will spend an excessive amount of time hiring and training new employees, and doing the work for the missing employees.
In spite of the need for information on the dairy labor market (wages, benefits, training), detailed information on the subject has not been collected previously.

\section{Labor survey}

During a 1991 study to examine dairy labor wages, benefits and training, dairy owners throughout California were surveyed. The survey was designed to accomplish the following objectives: (1) Collect baseline information on wages and benefits for dairy labor statewide. (2) Develop a profile of typical training and management practices for dairy labor statewide. (3) Collect baseline herd management and production data. (4) Determine whether any correlations exist between herd size, production and

TABLE 1. Survey production averages compared to California Dairy Herd Improvement Association (DHIA)

\begin{tabular}{lrr}
\hline \hline & Survey & DHIA \\
\hline Herd Size (cows) & 680 & 632 \\
Milk Production (lb) & 19,867 & 19,808 \\
Somatic Cell Count (cells/ml) & 154,366 & 224,000 \\
\hline
\end{tabular}

management, and labor compensation and labor management techniques.

The more than 240 responses received represented $10 \%$ of the state's dairies. Some surveys were completed by personal interview (19\%); the rest were mailed. Producers were chosen for interview at random from San Joaquin Valley counties on the Grade A producer list. Those not selected for interviews were mailed surveys to be completed on the farm and returned by mail.

The survey was divided into three sections. The first section asked questions about business structure, herd size and production, milk quality, calf mortality and use of technologies common to the industry (somatic cell counts, which measure udder health and milk quality, and artificial insemination). The second section requested information on scheduling, training, job descriptions and work performance. The last section contained questions on wages, benefits, incentive pay, housing and use of professional services (veterinarian, nutritionist). Data analysis of the information included simple descriptive statistics, such as means and percentages, and group comparisons using a one-way analysis of variance or chi-square test of independence in a two-way frequency table. For purposes of comparison, the dairies were grouped according to herd size and union or non-union membership of employees.

\section{Profile of respondents}

The majority of employers reporting $(63 \%)$ had herds of more than 400 cows and $70 \%$ produced above the state average of $19,000 \mathrm{lb}$ of milk per cow per year. The majority of dairies were structured as individually owned businesses $(34 \%)$ or as partnerships $(45 \%)$. Of the remaining dairies, $20 \%$ were incorporated and $2 \%$ were held in a trust. Regardless of business structure, $88 \%$ of all dairies reporting were owned/operated by a family member; $33 \%$ of herd managers were family members. Most herds (86\%) milked two times a day. Most (86\%) used somatic cell count information to make decisions on managing cows and $93 \%$ raised their own heifers. Demographic 
data on sample herds closely matched state Dairy Herd Improvement Association (DHIA) averages overall (table 1). The number of responding dairies (both union and non-union) was recorded by region (fig. 1). Herd size increased in the southern parts of the state (fig. 2).

\section{Labor management practices}

Most of the responding owners ( $82 \%$ ) encouraged employees to learn English, but only $8 \%$ used written job descriptions to describe the duties and responsibilities of a particular job title. Staff meetings were not often used as a means of communicating with employees $(20 \%)$, nor did a majority of employers (39\%) regularly evaluate employee performance on an individual basis. However, close to half of the employers $(46 \%)$ offered additional training for employees after the initial hiring and training. Ninety percent of employers instructed their staff specifically in the detection and treatment of mastitis.

Figure 3 shows there were no significant differences in the use of these managerial practices among dairies grouped according to herd size.

Regardless of job title, most employees worked 6 days per week. However, a wide variety of schedules were reported, from no formal schedule to 25 days on and 4 days off. Most dairy labor worked 8 to 9 hours a day.

Those responsible for training new workers differed significantly, depending on herd size. On larger dairies, the owner was least likely to be involved in training new employees. Authority for new-hire training was

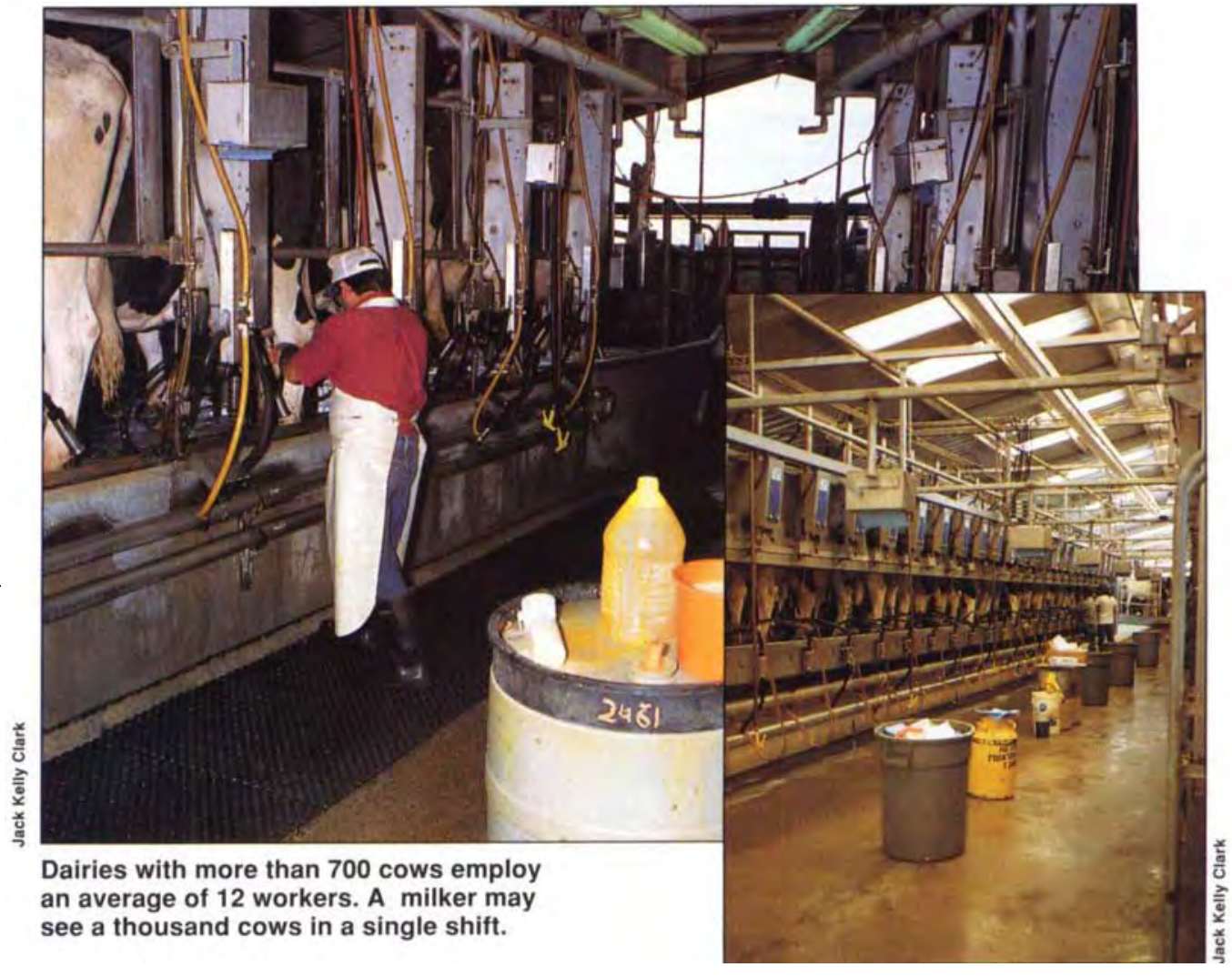

shared and/or delegated more frequently on larger dairies; owners of dairies with fewer than 400 cows took sole responsibility for training new employees most of the time (fig. 4).

\section{Number of employees}

Larger dairies had a higher cow-toemployee ratio than smaller dairies. Dairies of more than 700 cows averaged 151 cows per employee; dairies with fewer than 250 cows averaged 82 cows per employee. Dairies with fewer than 250 cows employed 3.5 workers on average; dairies with more than 700 cows employed 12 workers. The largest number of employees reported for any dairy was 31 (1,900 cows).

\section{Wages and benefits}

Wages were significantly higher for dairy employees belonging to unions, regardless of a worker's job title (table 2). Dairies with unions generally had larger herds than other dairies in the same region of the state, even in Southern California (fig. 5). Even when the union dairies were removed from the analysis, salaries were significantly higher $(\mathrm{p}<.01)$ for herd manag-

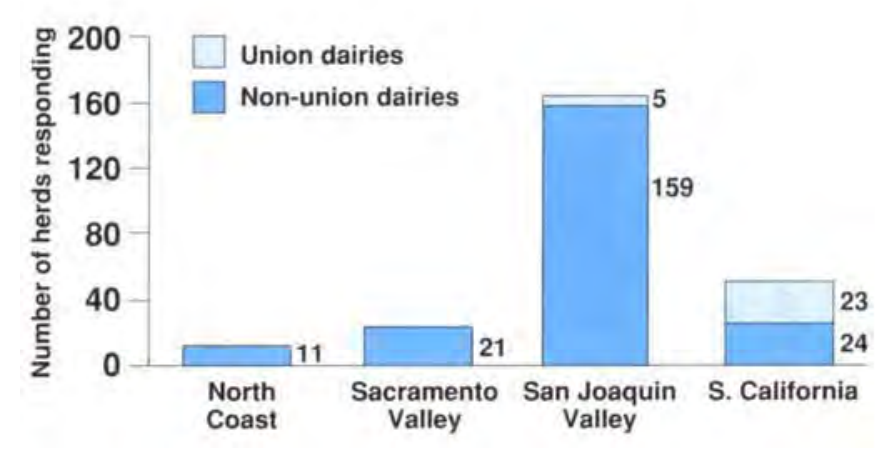

Fig. 1. Regional response to the survey.

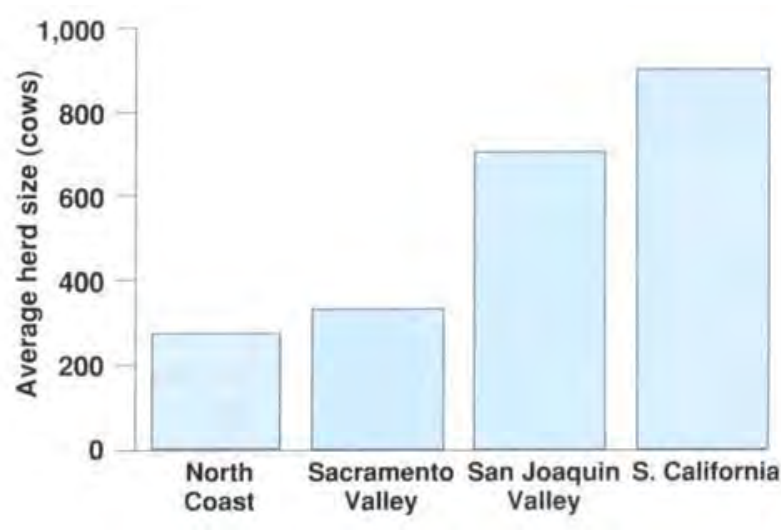

Fig. 2. Average herd size of dairies responding by region. 


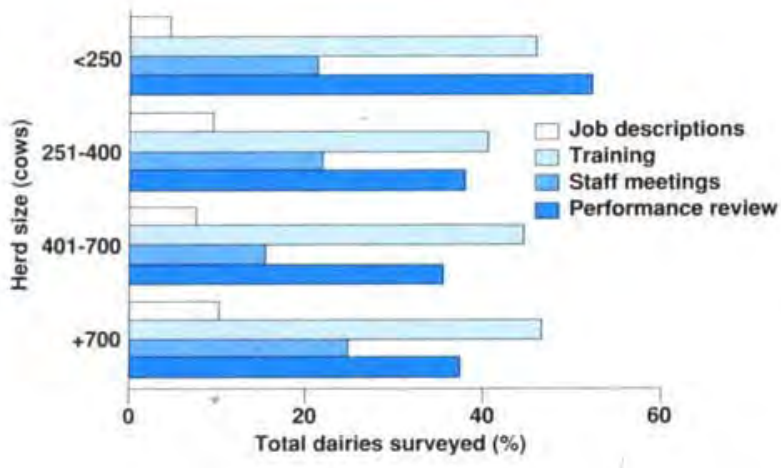

Fig. 3. Percentage of dairies using managerial practices (by herd size). Training is continuing education on or off the farm to increase skills and update knowledge of experienced employees. Staff meetings are regular meetings for all workers to inform them of current business issues and goals.

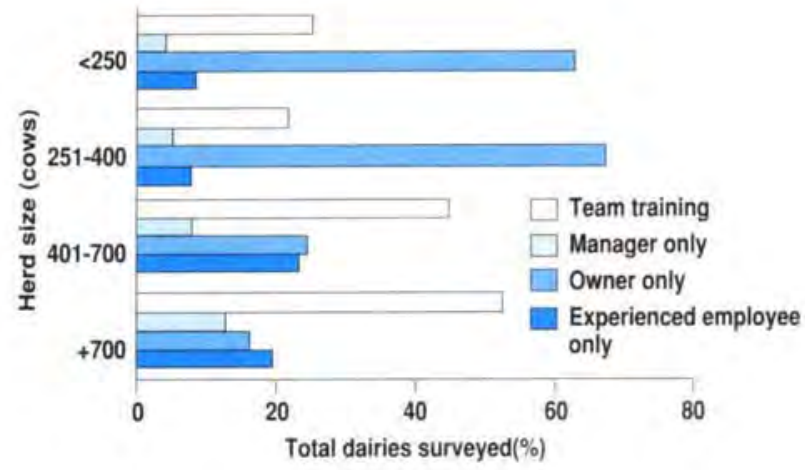

Fig. 4 Delegation of new employee training responsibilities on the dairy. Team training is any combination of owner, manager and experienced employees. There were significant differences ( $p<.01)$ in delegation of training responsibilities between herd size groups based on $\chi^{2}$ test of independence in a twoway frequency table.

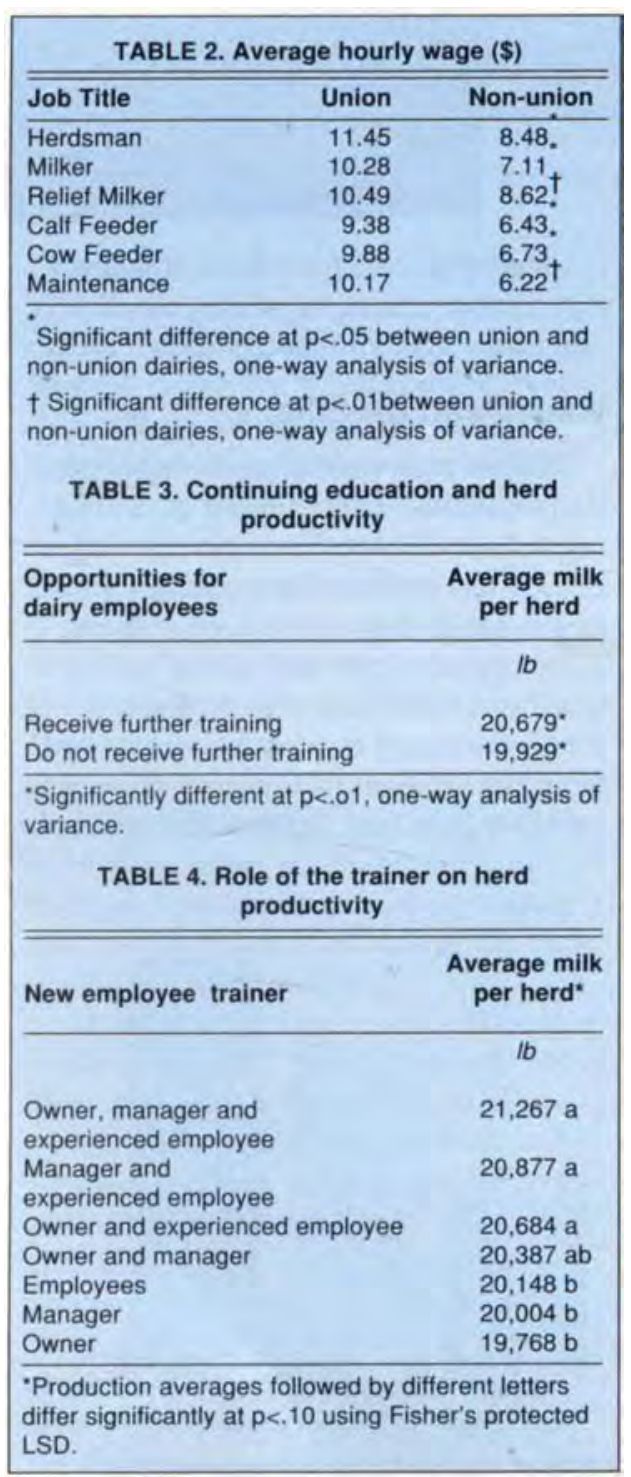

ers and milkers on larger dairies. However, there were no significant differences in wages for other job categories among dairies grouped according to herd size.

Figure 6 shows the percentage of dairies offering benefits, also grouped according to herd size. With the exception of paid holidays ( $p<.05)$, herd size has a highly significant ( $p<.01)$ effect on benefits offered to employees.

As the three tend to occur simultaneously, it was not possible to separate location, herd size and union effects on wages and benefits. The percentage of unionized dairies increased with herd size. Only $2.1 \%$ of dairies with herds of fewer than 250 cows were unionized; the number rose slightly, to $2.4 \%$, for herds of 251 to 400 cows. The percentage of unionized dairies increased to $10.8 \%$ for herds with 401 to 700 cows and was $23.9 \%$ for those herds of more than 700 cows.

\section{Production versus management}

Producers responding to the survey did not differ significantly in production by region, although those with herds of 400 to 700 cows reported slightly higher production levels and lower somatic cell counts than producers with larger or smaller herds.

Production was slightly higher for dairies that regularly offered employees further training after hire (table 3 ), and used a team approach (combining management and skilled labor) to train new employees (table 4). As expected, production averages for herds were inversely correlated to somatic cell counts. Dairies hiring unionized labor did not have significantly higher production, lower somatic cell count or less calf mortality than non-union dairies.

Obviously, more money for workers does not guarantee higher production or profits for dairies. However, a stable, satisfied work force is very important to dairy owners. Labor costs

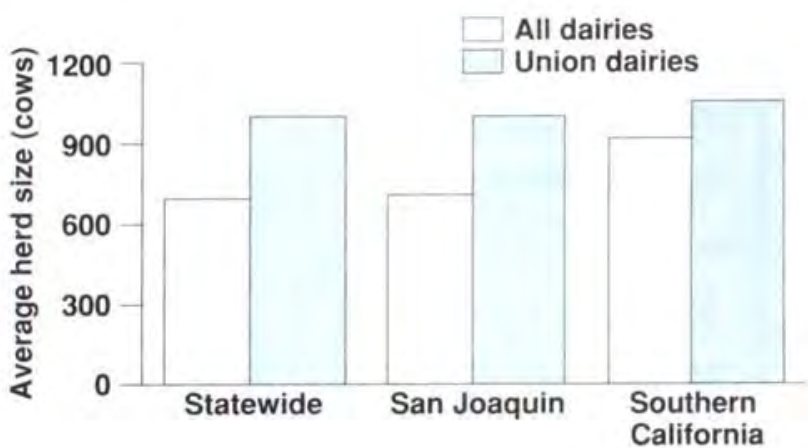

Fig. 5. Average herd size for union dairies compared to the regional average. 

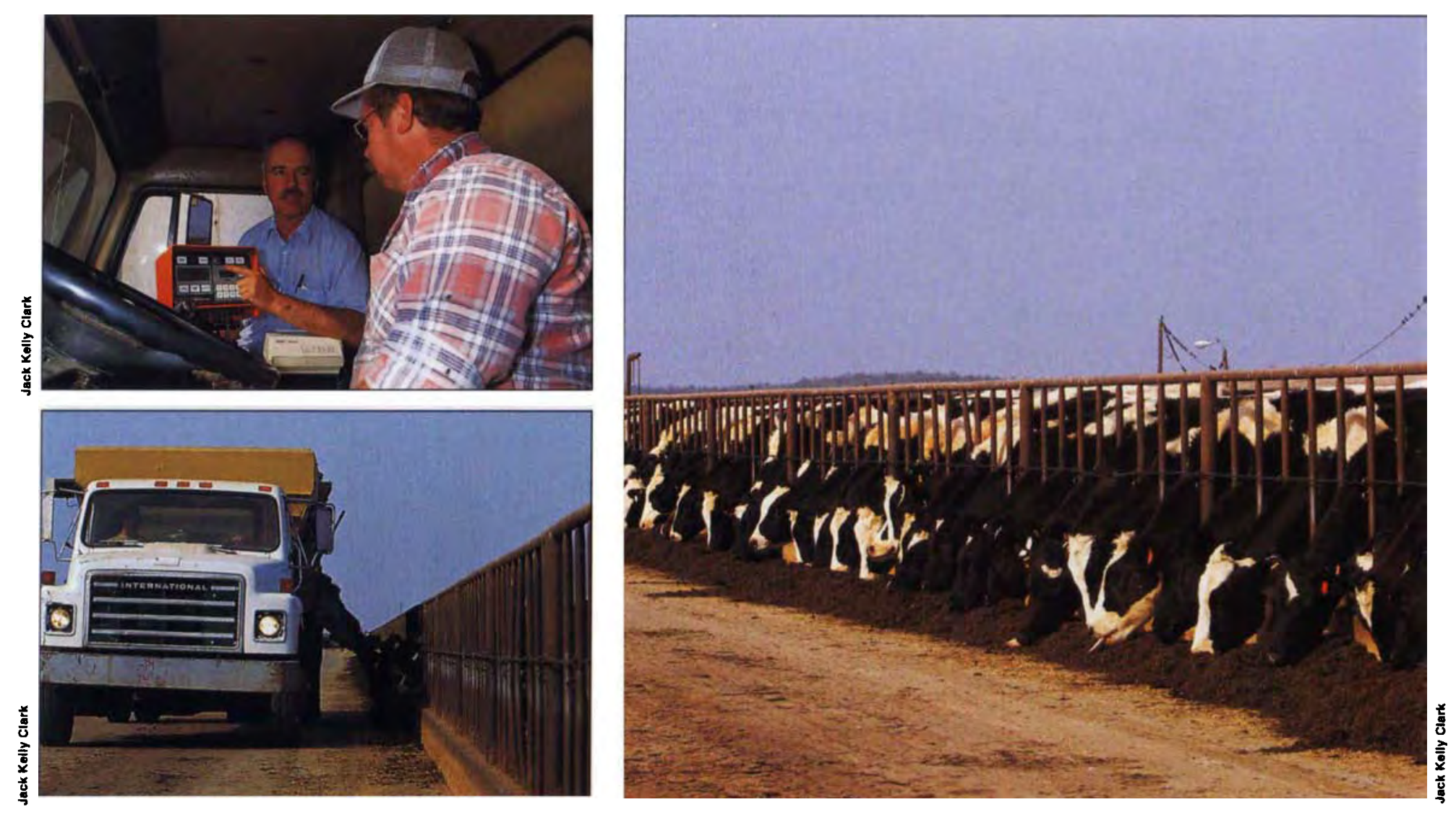

account for roughly $10 \%$ of all milk production costs, but labor management issues can mean big headaches for dairy owners. Respondents to the survey from all parts of California often stated effective labor management was the biggest challenge they faced.

\section{How big is too big?}

Because very large dairies (700-plus cows) did not show a production advantage over dairies in the $400-$ to 700 - cow range, owners of very large dairies may be gaining efficiencies of scale, but could be misdirected if they also expect larger herds to be the highest producing herds.

Survey results indicate several other trends. (1) Managerial practices appear to be more important in influencing productivity and product quality on the farm than wages and benefits alone. (2) Large dairy size may force a more effective style of management

Fig. 6. Paid benefits available to employees. Benefits offered differed significantly by herd size groups ( $p<.01)$, except for holidays $(p<.05)$, based on a $\chi^{2}$ test of independence in a two-way frequency table.

\begin{abstract}
Adoption of newer technologies has put a premium on management skills. Upper left, a supervisor shows an employee how to operate computerized feed equipment. Lower left, a feed wagon dispenses feed. Feeding may be the sole responsibility of an employee. Above, nutrition of dairy cattle influences dairy productivity.
\end{abstract}

(team training) because more responsibility must be delegated. (3) The interaction of union, size and location effects may cause dairies to offer more competitive wage and benefit pack-

ages in an effort to attract and keep employees.

Although smaller California dairies offer employees certain advantages (such as more direct input into the dairy operations, and more varied job responsibilities), this survey indicates that they will earn lower wages and receive fewer benefits than employees on larger dairies (400-plus cows).

\section{B. Reed is Dairy and Forage Farm Advi- sor, Glenn County. \\ The author thanks Gail Nishimoto and Carol Adams of the Biometrical Services Unit for their invaluable assistance in this project.}

